DOI: $10.17805 /$ trudy.2015.4.13

\title{
ПЕРВОЕ ЗАСЕДАНИЕ МЕЖДУНАРОДНОГО НАУЧНОГО СЕМИНАРА «ШЕКСПИР В МЕЖДИСЦИПЛИНАРНЫХ ГУМАНИТАРНЫХ ИССЛЕДОВАНИЯХ»"
}

\author{
B. С. Макаров \\ (Московский гуманитарный университет)
}

Аннотация: В статье дан обзор первого заседания Международного научного семинара «Шекспир в междисциплинарных гуманитарных исследованиях», который прошел 18 июня 2015 г. в Государственном институте искусствознания (2. Москва). Организаторами постоянно действующего семинара выступили Шекспировская комиссия РАН, Московский гуманитарный университет и Государственный институт искусствознания.

Ключевые слова: Шекспир, шекспироведение, семинар, обзор.

\section{ST SESSION OF THE INTERNATIONAL RESEARCH SEMINAR “SHAKESPEARE IN INTERDISCIPLINARY RESEARCH IN THE HUMANITIES"}

\author{
V. S. Makarov \\ (Moscow University for the Humanities)
}

Abstract: This is an overview of the first session of the International research seminar "Shakespeare in Interdisciplinary Research in the Humanities" which was held on June 18, 2015 at the State Institute for Arts Studies (Moscow, Russia). The permanent seminar is organized by the Shakespeare Committee of the Russian Academy of Sciences, Moscow University for the Humanities and the State Institute for Arts Studies.

Keywords: William Shakespeare, Shakespeare studies, seminar, overview.

Шекспир как один из главных «культурных героев» мировой цивилизации - наиболее подходящая фигура для того, чтобы объединить представителей различных наук о человеке и культуре. Международный научный семинар «Шекспир в междисциплинарных гуманитарных исследованиях» стремится создать площадку для разработки междисциплинар-

Статья подготовлена в рамках проекта «Международный научный семинар «Шекспир в междисциплинарных гуманитарных исследованиях» (Грант РГНФ № 15-0414085-2). 
ных практик анализа художественного текста и его роли в исторических, культурологических, филологических, философских, театроведческих и других исследованиях. В отечественном шекспироведении подобных прецедентов ранее не было.

Сильной стороной российских «Шекспировских чтений» всегда был междисциплинарный подход: в ее работе участвовали филологи, театроведы, искусствоведы, культурологи и др. Эту традицию продолжили более камерные научные мероприятия - постоянно действующие семинары ИФПИ МосГУ, посвященных проблемам творчества Шекспира и развитию тезаурусного подхода: «Шекспировские штудии» (рук. Н. В. Захаров), «Тезаурусный анализ мировой культуры» (рук. В. А. Луков). Опыт проведения междисциплинарных гуманитарных семинаров актуален для решения проблем междисциплинарного взаимодействия ученых гуманитариев.

18 июня 2015 г. в кинозале Государственного института искусствознания (Москва, Козицкий переулок, 5) при поддержке Российского гуманитарного научного фонда (грант № 15-04-14085-г) состоялось первое заседание Международного научного семинара «Шекспир в междисциплинарных гуманитарных исследованиях». Организаторами постоянно действующего семинара выступили Шекспировская комиссия РАН, Московский гуманитарный университет и Государственный институт искусствознания.

С докладом «Эмблемы, экфразы, формулы пафоса. Образность шекспировской эпохи на стыке теории литературы, искусствоведения и психологии» выступила кандидат филологических наук, приглашенный доцент Европейского гуманитарного университета (Вильнюс, Литва) Виктория Александровна Мусвик. То, что автор назвала «разрастанием» исследования текстов шекспировской эпохи, было показано на двух примерах.

Первый из них - книги эмблем и эмблематическая традиция в том виде, как она представлена в «гибридных жанрах» - сборниках портретов выдающихся людей, дружеских альбомах (alba amicorum), книгах костюмов, книгах цитат и афоризмов (commonplace books), мифографиях и т. д. В. А. Мусвик показала, как эти книги и альбомы становились фокусом эмоциональных сообществ, средством выражения дружеских чувств и коллективной идентичности.

Второй пример - экфразис из «Новой Аркадии» Филипа Сидни, описывающий изображение печали и меланхолии. На его примере было показано, как литературный текст оказывается более понятен с помощью методологии истории эмоций и школы Аби Варбурга. «Формулы пафоса», которыми можно описать, в частности, фигуру скорбящей Венеры, скрывшей лицо под покровом, могут быть прослежены начиная от античного искусства и вплоть до книжных обложек начала XXI века. 
В качестве респондента на семинаре выступил доктор филологических наук, ведущий научный сотрудник Института мировой культуры МГУ им. М. В. Ломоносова, доцент факультета истории искусства РГГУ Александр Викторович Марков. Хорошо дополнило доклад В. А. Мусвик стремление респондента показать «точки смыкания дисциплин». Примером того, как художественный образ, биографический текст и моральный смысл были тесно сплетены на протяжении веков, респондент избрал наследие мыслителей-гуманистов Паоло Джовио и Юста Липсия. Говоря о Джовио, А. В. Марков остановился на грамматической революции как проекта переустройства наук на базе грамматики. Наследие Липсия помогает понять то, какое место занимает язык (в частности, идеальная латынь) в создании правильной системы наук и, соответственно, в понимании «нравов, сопровождающих профессию». От интеллектуала, занятого профессиональным трудом, остается реликвия или эмблема. Грамматист же, став философом, указывает путь от созерцания объектов к созерцанию самого характера природы.

Семинар завершился общей дискуссией. В заседании приняли участие: доктор искусствоведения, профессор РАТИ-ГИТИС заведующий сектором современного искусства Запада ГИИ, председатель Шекспировской комиссии РАН Алексей Вадимович Бартошевич; доктор философии (PhD), кандидат филологических наук директор Центра теории и истории культуры Института фундаментальных и прикладных исследований МосГУ, ученый секретарь Шекспировской комиссии РАН Николай Владимирович Захаров; кандидат филологических наук заместитель директора Центра теории и истории культуры ИФПИ МосГУ, член-корреспондент Международной академии наук (IAS) Владимир Сергеевич Макаров; доктор филологических наук профессор кафедры всемирной литературы Московского педагогического государственного университета, президент Российской ассоциации изучения проблем англистики Елена Николаевна Черноземова; заслуженный работник культуры РФ, заместитель заведующего отделом ГМИИ им. А. С. Пушкина, переводчик Александр Николаевич Баранов; доктор искусствоведения ведущий научный сотрудник сектора современного искусства ГИИ Валентина Александровна Ряполова; кандидат филологических наук доцент кафедры истории театра и кино историко-филологического факультета Института филологии и истории РГГУ Галина Алексеевна Сокур; кандидат философских наук заместитель директора Центра теории и истории культуры ИФПИ МосГУ Борис Николаевич Гайдин, студенты московских вузов и др. 
Макаров Владимир Сергеевич - кандидат филологических наук, заместитель директора центра теории и истории культуры, Институт фундаментальных и прикладных исследований, Московский гуманитарный университет. Адрес: 111395, Москва, ул. Юности, 5, корп.6. Тел.: +7 (499) 374-59-30. Эл. адрес: mail@vmakarov.name

Makarov Vladimir Sergeyevich, Candidate of Philology, Deputy Director, Center for the theory and history of culture, Institute of Fundamental and Applied Studies, Moscow University for the Humanities. Postal address: 5 Bldg. 6 Yunosti St., 111395 Moscow, Russian Federation. Tel.: +7 (499) 374-59-30.E-mail: mail@ vmakarov.name 